\title{
Nauki historyczne, nauki eksperymentalne i metoda naukowa
}

Wielu naukowców sadzi, że istnieje jedna, interdyscyplinarna metoda uprawiania dobrej nauki. Wzorcowe przyktady czerpane sa jednak z obrębu klasycznych nauk eksperymentalnych. Czasem, kiedy hipotez o charakterze historycznym nie można testować $w$ kontrolowanych warunkach laboratoryjnych, twierdzi się, że badania historyczne maja gorsza jakość niż badania eksperymentalne. Celem niniejszego artykułu jest wykazanie, na podstawie przykładów z różnych dyscyplin historycznych, że to przekonanie jest błędne. Po pierwsze, poglad o rzekomej wyższości badań eksperymentalnych wynika z przyjęcia takich koncepcji metodologii naukowej (indukcjonizmu baconowskiego i falsyfikacjonizmu), które maja poważne mankamenty, zarówno na ptaszczyźnie logicznej, jak też jako ujęcia rzeczywistych praktyk naukowców. Po drugie, chociaż między metodologiami nauk eksperymentalnych i nauk historycznych zachodza zasadnicze różnice, zwiqzane sq one z pewna wszechobecna wtaściwościa świata przyrody czasowa asymetria przyczynowości. Nie da się zatem utrzymać twierdzenia, że nauki historyczne sa pod względem metodologicznym gorsze od nauk eksperymentalnych.

\footnotetext{
${ }^{*}$ Carol E. Cleland, „Historical Science, Experimental Science, and the Scientific Method", Geology, November 2001, vol. 29, no. 11, s. 987-990, http://spot.colorado.edu/ cleland/ articles/Cleland.Geology.pdf (14.09.2011). Za zgodą Redakcji z języka angielskiego przełożył: Dariusz Sagan. Recenzent: Krzysztof SzlachCic, Instytut Filozofii Uniwersytetu Wrocławskiego.
} 


\section{Wprowadzenie}

Metody eksperymentalne powszechnie przedstawiane są jako wzorzec testowania hipotez: metoda naukowa, o której często mowa w tekstach wprowadzających do zasad uprawiana nauki, wzorowana jest właśnie na nich. Jednakże nie wszystkie hipotezy naukowe można testować w laboratorium. Dobrymi przykładami są hipotezy historyczne, postulujące przeszłe przyczyny zjawisk obserwowanych obecnie. Mimo iż hipotezy o charakterze historycznym zwykle kojarzone są $\mathrm{z}$ takimi dziedzinami jak paleontologia $\mathrm{i}$ archeologia, to powszechnie występują one także $\mathrm{w}$ geologii, planetologii, astronomii i astrofizyce. Najlepiej znane ich przykłady to hipotezy: dryfu kontynentalnego, wymarcia dinozaurów na skutek uderzenia meteorytu, powstania Wszechświata w Wielkim Wybuchu oraz — ostatnio - hipoteza, że istnieją planety krążące wokół odległych gwiazd. Wspólne im wszystkim jest to, że thumaczą zaobserwowane zjawiska (na przykład komplementarne kształty wschodniego wybrzeża Ameryki Południowej i zachodniego wybrzeża Afryki, występowanie irydu i stopionego kwarcu na granicy Kredy i Trzeciorzędu (K-T), izotropowe promieniowanie tła kosmicznego o temperaturze trzech stopni kelwina czy też niestabilny ruch pewnych gwiazd), odwołując się do ich przeszłych przyczyn. Stosowanie symulacji komputerowych nie zmienia faktu, że mają one historyczny charakter.

Mimo popularności poglądu, że wszyscy dobrzy naukowcy posługują się jedną metodą testowania hipotez, analiza praktyk przedstawicieli nauk historycznych i nauk eksperymentalnych ujawnia znaczące różnice między nimi. Klasyczne badania eksperymentalne obejmują formułowanie przewidywań i ich sprawdzanie - najlepiej w kontrolowanych warunkach laboratoryjnych. Natomiast w badaniach historycznych proponowane są wyjaśnienia obserwowalnych zjawisk, wyrażone w kategoriach nieobserwowalnych przyczyn, niedających się w pełni odtworzyć w laboratorium. Wielu naukowców reprezentujących nauki eksperymentalne dostrzega tę różnicę, a jednak utożsamiając dobrą praktykę naukową z własną pracą, czasem umniejszają oni 
tezy nauk historycznych, twierdząc, że nie można ich sfalsyfikować lub że mająca potwierdzać je argumentacja przypomina takie sobie bajeczki (tak Rudyard Kipling nazywał zmyślone przez siebie opowiastki, na przykład o tym, skąd lamparty mają cętki). Wymownym tego przykładem jest zdumiewająca liczba fizyków i chemików, którzy krytykują naukowy status ewolucjonizmu neodarwinowskiego. Najbardziej cięta krytyka nauk historycznych wyszła jednak z ust redaktora Nature, Henry'ego Gee, ${ }^{1}$ który otwarcie odmówił naukowego statusu wszystkim hipotezom dotyczącym odległej przeszłości. Stwierdził on, że „nie da się ich sprawdzić eksperymentalnie, a więc są nienaukowe [...] Nauka nie może mieć charakteru historycznego".

Niniejszy artykuł wyjaśnia, dlaczego nauki historyczne nie są w gorszej sytuacji od nauk eksperymentalnych, gdy idzie o testowanie hipotez. Po pierwsze, zarzuty w stylu Henry'ego Gee opierają się na błędnym pojmowaniu praktyk eksperymentalnych i ogólnej metodologii nauk. Po drugie, różnice metodologiczne, które rzeczywiście istnieją między naukami historycznymi a naukami eksperymentalnymi, mają związek z pewną wszechobecną właściwością świata przyrody: asymetrią przyczynową między zdarzeniami teraźniejszymi a przeszłymi, z jednej strony, i zdarzeniami teraźniejszymi a przyszłymi, z drugiej. O ile praktyki w obu wyżej wspomnianych naukach mają na celu ocenę hipotez na podstawie danych przyrodniczych i o ile charakter tych informacji jest różny, o tyle żadnej $\mathrm{z}$ tych nauk nie można uznać za bardziej obiektywną lub bardziej racjonalną od drugiej.

\section{Metoda naukowa}

Hipotezy testowane w ramach klasycznych badań eksperymentalnych mają charakter ogólny, na przykład: „miedź zawsze zwiększa swoją objętość, gdy jest podgrzewana". Z hipotezy H dedukowane jest twierdzenie warunkowe $\mathrm{T}$ (konsekwencja testowa). $\mathrm{T}$ wskazuje, co musi się zdarzyć, jeśli $\mathrm{H}$ jest prawdziwa. Konsekwencje testowe mają

\footnotetext{
${ }^{1}$ H. Gee, In Search of Deep Time, The Free Press, New York 1999.
} 
następującą postać: jeżeli spełniony jest warunek W (podgrzanie kawałka miedzi), to nastąpi zdarzenie $Z$ (zwiększenie objętości miedzi). Konsekwencje testowe umożliwiają przeprowadzanie eksperymentów. Warunek W jest sztucznie wytwarzany w laboratorium i badacze sprawdzają, czy zachodzi zdarzenie $Z$.

Jak dokonywana jest ewaluacja hipotez w świetle świadectw uzyskanych w eksperymencie? W tekstach dotyczących nauki, od szkoły podstawowej po szkołę wyższą, pod pojęciem „metody naukowej” zawsze rozumie się jedno z dwóch ujęć (lub ich kombinację) — naukowy indukcjonizm lub falsyfikacjonizm. Naukowy indukcjonizm, zwykle przypisywany Francisowi Baconowi, głosi, że wystąpienie przewidywanego zdarzenia $\mathrm{Z}$ w warunkach $\mathrm{W}$ stanowi świadectwo potwierdzające hipotezę H. A jeśli uzyska się wystarczająco dużo odpowiednich pozytywnych świadectw, to społeczność naukowa powinna przyjąć $\mathrm{H}$. Niestety, naukowy indukcjonizm boryka się z odwiecznym problemem indukcji: żaden skończony zbiór świadectw nie może konkluzywnie dowieść uniwersalnej generalizacji. Wielu naukowców, którzy mają świadomość problemu indukcji, opowiada się za falsyfikacjonizmem, głoszącym, że hipotez wprawdzie nie da się dowieść, ale można je obalić. W odróżnieniu od indukcjonizmu, falsyfikacjonizm otrzymuje wsparcie od logiki. Wykorzystuje on poprawny logicznie schemat wnioskowania zwany modus tollens. Zgodnie z modus tollens dana generalizacja jest fałszywa, jeżeli istnieje choć jeden sprzeczny z nią fakt. Hipoteza, że miedź zawsze zwiększa swoją objętość, gdy jest podgrzewana, byłaby zatem fałszywa, gdyby choć w jednym przypadku miedź nie zwiększała swojej objętości przy podgrzewaniu. Tak więc mimo iż nigdy nie można dowieść tej hipotezy (ponieważ żadna ilość testów nie może wykluczyć możliwości, że jakiś podgrzewany kawałek miedzi nie zwiększy swojej objętości), wydaje się, że da się ją obalić. W kręgach filozoficznych falsyfikacjonizm kojarzony jest z Karlem Popperem,${ }^{2}$ który na podstawie logicznej wiedzy o modus tollens stworzył szczególne ujęcie praktyki naukowej. Podstawowym

\footnotetext{
${ }^{2}$ K.R. POPPER, Droga do wiedzy. Domysly i refutacje, przeł. Stefan Amsterdamski, $B i-$ blioteka Współczesnych Filozofów, Wydawnictwo Naukowe PWN, Warszawa 1999.
} 
wymogiem Popperowskiego falsyfikacjonizmu jest poddanie hipotezy „surowemu sprawdzianowi”, którego wynik — jak wskazuje wiedza towarzysząca - $\mathrm{z}$ dużym prawdopodobieństwem może ją obalić. Jeśli przewidywanie zawiedzie, to na gruncie modus tollens hipoteza powinna być bezwzględnie odrzucona. W myśl falsyfikacjonizmu próby potwierdzenia hipotezy nie spełniają kryterium naukowości.

Od ponad 50 lat filozofowie wiedzą jednak, że falsyfikacjonizm jest ujęciem głęboko wadliwym. Boryka się z dwoma podstawowymi trudnościami. Po pierwsze, w każdej rzeczywistej sytuacji eksperymentalnej mamy do czynienia $\mathrm{z}$ wieloma założeniami pomocniczymi dotyczącymi sprzętu i warunków towarzyszących, nie wspominając o uznaniu prawdziwości innych powszechnie akceptowanych teorii. Gdy warunki te weźmie się pod uwagę, wnioskowanie logicznie uprawnione przez modus tollens ulega diametralnej zmianie. Za porażkę przewidywania odpowiadać może fałszywość jakiegoś założenia pomocniczego (nie zaś sprawdzanej hipotezy). Intuicyjnie wie o tym każdy student nauk przyrodniczych, ponieważ kolejne klasyczne eksperymenty na ćwiczeniach laboratoryjnych często nie dają oczekiwanych rezultatów nie dlatego, że testowana hipoteza jest fałszywa, lecz na przykład z powodu wadliwości sprzętu lub zanieczyszczenia próbki. Co więcej, trudności tej nie da się obejść poprzez zmienianie warunków, w których hipoteza podlega sprawdzeniu, gdyż liczba warunków pomocniczych w dowolnej rzeczywistej sytuacji jest nieznana i potencjalnie nieskończona. Nie sposób skontrolować je wszystkie. Słynna dyrektywa Poppera, aby chwycić byka za rogi i odrzucić hipotezę, gdy przewidywanie zawodzi, nie ma mocy logicznej. Ponadto, jak wykazał Kuhn, ${ }^{3}$ w praktyce naukowcy prawie nigdy nie stosują falsyfikacjonizmu. W obliczu nieudanego przewidywania nieustannie poszukują warunków innych niż $\mathrm{W}$, które mogą za to odpowiadać. Korzystają tym samym z logicznie dopuszczalnej możliwości ocalenia hipotezy dzięki odrzuceniu jakiegoś założenia pomocniczego. Dobrym przykładem jest reakcja dziewiętnastowiecznych astronomów na zaob-

${ }^{3}$ T.S. KuHN, Struktura rewolucji naukowych, przeł. Helena Ostromęcka i Justyna Nowotniak, Fundacja Aletheia, Warszawa 2001. 
serwowane perturbacje orbity Uranu — jego orbita odchylała się od przewidywań klasycznej mechaniki newtonowskiej. Astronomowie nie zachowali się jak dobrzy falsyfikacjoniści, nie odrzucili bowiem teorii Newtona, lecz zrezygnowali z założenia, że Uran jest ostatnią planetą Układu Słonecznego i dzięki temu odkryli Neptuna. Z historii tej wypływa morał, że odrzucenie hipotezy w obliczu nieudanego przewidywania bywa niekiedy złym rozwiązaniem. To nie przypadek, że logika zapewnia możliwość odrzucenia założenia pomocniczego, nie zaś hipotezy. Krótko mówiąc, logika nie zmusza naukowców do zachowywania się tak, jak na dobrych falsyfikacjonistów przystało, i uczeni rzeczywiście tak nie postępują. Falsyfikacjonizm nie może być zatem podstawą uzasadnienia tezy, że w jednych naukach testowanie hipotez jest łatwiejsze niż w innych.

Przyjrzyjmy się bliżej temu, co rzeczywiście robią przedstawiciele nauk eksperymentalnych, gdy testują jakąś hipotezę. Warunek testowy $\mathrm{W}$, określony przez sprawdzaną hipotezę, jest ciągle taki sam (powtarzalny), natomiast inne warunki ulegają zmianie. Jeśli wcześniej zawiedzie jakieś przewidywanie, to praktyka naukowców przypomina tę, którą potępiał Popper, czyli jest doraźną próbą uchronienia hipotezy przed obaleniem poprzez odrzucenie jakiegoś założenia pomocniczego. Istnieje jednak alternatywna interpretacja: praktykę tę można postrzegać jako próbę ocalenia hipotezy przed zwodniczym obaleniem. Należy zauważyć, że ten sam proces utrzymywania niezmienności W przy jednoczesnym różnicowaniu warunków pomocniczych zachodzi też, gdy test hipotezy przynosi pozytywny rezultat. Co więcej, można nawet zrezygnować $\mathrm{z}$ warunku $\mathrm{W}$, aby ustalić, czy jest on potrzebny do uzyskania pozytywnego wyniku. Mimo iż tego typu reakcje na udane testy powierzchownie przypominają próby falsyfikacji, po chwili zastanowienia nasuwa się wniosek, że wcale tak nie jest. Okazuje się bowiem, że nie spełniają one wymogu Poppera, zgodnie z którym sprawdziany muszą być „surowe”. Hipoteza przeszła pomyślnie podobne testy i nikt nie oczekuje jej obalenia przy kolejnych. A gdyby nawet tak się stało, to i tak hipoteza nie zostałaby automatycznie odrzucona. Patrząc z tej perspektywy, praktyka ta bardziej przypomina 
próbę uchronienia hipotezy przed zwodniczym potwierdzeniem. Innymi słowy, dokładniejsza analiza działalności przedstawicieli nauk eksperymentalnych ujawnia, że zależy im głównie na ochronie swoich hipotez przed wynikami fałszywie negatywnymi i wynikami fałszywie pozytywnymi, nie zaś na podjęciu bezwzględnej próby ich sfalsyfikowania. Jest to postępowanie jak najbardziej sensowne, ponieważ jak już wiemy — w każdym rzeczywistym teście danej hipotezy występuje wiele założeń pomocniczych, które mogą wpłynąć na wynik eksperymentu niezależnie od prawdziwości tej hipotezy.

Mając tego świadomość, przystąpmy do analizy rzekomo problematycznych różnic między naukami historycznymi a naukami eksperymentalnymi. Reprezentanci tych pierwszych nauk są równie zauroczeni falsyfikacjonizmem, jak przedstawiciele drugich. Na przykład trzej wybitni geologowie, ${ }^{4}$ omawiając w swoim podręczniku kwestię wymarcia dinozaurów, stwierdzili: ,zgodnie z główną zasadą metody naukowej hipotez nie można dowieść, lecz jedynie obalić". Niemniej jednak ewaluacja hipotez o charakterze historycznym nie spełnia raczej wymogów falsyfikacjonizmu. Świetnym przykładem jest teoria Wielkiego Wybuchu, która tłumaczy powstanie Wszechświata. Postuluje ona konkretne zdarzenie (pierwotną eksplozję), aby wyjaśnić coś, co obserwujemy obecnie, to jest promieniowanie tła kosmicznego o temperaturze trzech kelwinów, które po raz pierwszy wykryto za pomocą anten satelitarnych w latach sześćdziesiątych dwudziestego wie$\mathrm{ku}$. Ślady, takie jak wspomniane promieniowanie, stanowią świadectwo na rzecz hipotez formułowanych w naukach historycznych, podobnie jak udane przewidywania przemawiają za generalizacjami testowanymi w naukach eksperymentalnych. Jednakże w naukach historycznych istnieje niewielka lub w ogóle nie ma możliwości przeprowadzania kontrolowanych eksperymentów. Dzieje się tak dlatego, że rozpatrywany przedział czasowy jest zbyt długi i/lub istotne warunki testowe są zbyt złożone i zależne od nieznanych bądź słabo zrozumia-

\footnotetext{
${ }^{4}$ L.R. Kump, J.F. Fasting, and R.G. Crane, The Earth System, Prentice-Hall, Englewood Cliffs, New Jersey 1999, s. 201.
} 
nych warunków zewnętrznych, przez co nie da się ich odtworzyć w laboratorium.

Nie oznacza to jednak, że hipotez dotyczących przeszłych zdarzeń nie można poddać testom. Jak zauważył geolog T.C. Chamberlin, ${ }^{5}$ dobrzy badacze, działający w obrębie nauk historycznych, kładą nacisk na formułowanie wielu alternatywnych hipotez (nie zaś tylko jednej). Jeśli chodzi o testowanie takich hipotez, to Chamberlin był z ducha falsyfikacjonistą. Każda hipoteza miała być poddana niezależnym surowym testom w nadziei, że któraś przejdzie je pomyślnie. Analiza rzeczywistych praktyk reprezentantów nauk historycznych ujawnia jednak, że skupiają się oni na szukaniu pozytywnych świadectw domniemanego dowodu (smoking gun). Ów domniemany dowód to ślad pozwalający uznać, że jedna $\mathrm{z}$ alternatywnych hipotez stanowi lepsze przyczynowe wyjaśnienie aktualnie obserwowanych śladów niż inne hipotezy.

Dobrym przykładem jest hipoteza uderzenia meteorytu, wyjaśniająca wymarcie dinozaurów. ${ }^{6}$ Przed rokiem 1980 istniało wiele różnych wyjaśnień wyginięcia tych stworzeń. Wśród wskazywanych przyczyn były: choroba, zmiana klimatu, aktywność wulkaniczna i uderzenie meteorytu. Po odkryciu sporych złoży irydu na granicy K-T uwagę skupiono na tej ostatniej możliwości. Iryd rzadko występuje na powierzchni Ziemi, ale duże jego koncentracje znajdują się w jej wnętrzu oraz w meteorach. Hipotezę uderzenia dużego meteorytu dodatkowo potwierdziło odkrycie stopionego kwarcu na granicy $\mathrm{K}-\mathrm{T}$, ponieważ nie znano żadnego mechanizmu wulkanicznego, który mógłby wytworzyć tak duże jego ilości. Przyczynowe połączenie impaktu z wymarciem dinozaurów wymagało jednak nieco więcej pracy. ${ }^{7}$ Obecność irydu i stopionego kwarcu nabrała charakteru „,domnie-

\footnotetext{
${ }^{5}$ T.C. Chamberlin, „The Method of Multiple Working Hypotheses”, Journal of Geology 1897, vol. 5, s. 837-848.

${ }^{6}$ L.W. Alvarez, W. Alvarez, F. Asaro, and H.V. Michel, „Extraterrestrial Cause for the Cretaceous-Tertiary Extinction”, Science 1980, vol. 208, s. 1095-1108.

${ }^{7}$ W.A. Clemens, J.D. Archibald, and L.J. Hickey, „Out with a Whimper Not a Bang”, $P a$ -
} 
manego dowodu" na rzecz hipotezy uderzenia meteorytu dopiero wtedy, gdy stało się jasne, że dinozaury zniknęły z powierzchni Ziemi w dość krótkim czasie po impakcie. Krótko mówiąc, wśród dostępnych hipotez i w świetle zgromadzonych świadectw (były to między innymi zapis kopalny, iryd, stopiony kwarc, krater) hipoteza uderzenia meteorytu stanowiła najbardziej wiarygodny mechanizm przyczynowy, który pozwalał zrozumieć wyginięcie dinozaurów.

Chociaż badania przeszłych zdarzeń często obejmują również pracę laboratoryjną, to mają inny cel niż klasyczne badania eksperymentalne. Nacisk kładziony jest głównie na analizę i takie wyostrzenie śladów, aby można je było zidentyfikować i właściwie zinterpretować. Na przykład przypuszczenie, że życie istnieje od 3,8 miliarda lat, opiera się na laboratoryjnej analizie proporcji izotopu węgla $\mathrm{w}$ drobinach skalnych mających średnicę zaledwie $10 \mu \mathrm{m}$ i ważących jedynie $20 \times 10^{-15}$ g. ${ }^{8}$ Przedstawiciele nauk historycznych czasem jednak sprawdzają w laboratorium założenia pomocnicze. Dobrym przykładem są eksperymenty Millera-Ureya, ${ }^{9}$ które uznano za potwierdzające hipotezę, że życie miało początek w pierwotnym bulionie, ale w istocie przemawiają one na rzecz założenia pomocniczego, zgodnie z którym niektóre cegiełki budulcowe życia (aminokwasy) można wytworzyć poprzez oddziaływanie wyładowaniami elektrycznymi na mieszaninę metanu, wodoru, amoniaku i wody. W tym kontekście należy zauważyć, że większość naukowców obecnie sądzi, że życie na Ziemi nie mogło powstać w warunkach badanych w eksperymencie MilleraUreya. Uważa się, że atmosfera wczesnej Ziemi nie zawierała dużych

leobiology 1981, vol. 7, s. 293-298.

${ }^{8}$ S.J. Mojzsis, G. Arrhenius, K.D. McKeegan, T.M. Harrison, A.P. Nutman, and C.R.L. Friend, „Evidence for Life on Earth Before 3,800 Million Years ago”, Nature 1996, vol. 384, s. 55-59.

${ }^{9}$ S.L. Miller, „A Production of Amino Acids Under Possible Primitive Earth Conditions", Science 1953, vol. 117, s. 528-529. 
ilości metanu lub amoniaku oraz że życie mogło wziąć początek w pobliżu głębokomorskich kominów wulkanicznych. ${ }^{10}$

Nie należy też mylić modelowania komputerowego, które jest dziś popularne w dziedzinie badań historycznych, z kontrolowanymi eksperymentami laboratoryjnymi. Komputer może co najwyżej określić konsekwencje hipotezy ze względu na niewielką liczbę dobrze odtworzonych, hipotetycznych warunków. Nie może natomiast ani wskazać, które $\mathrm{z}$ tych hipotetycznych warunków rzeczywiście zachodzą w jakimś konkretnym, modelowanym układzie fizycznym, ani odtworzyć wszystkich innych, potencjalnie istotnych, występujących w nim warunków fizycznych. Dobrym przykładem są pierwsze symulacje klimatu Ziemi jako kuli śniegu, które wskazywały, że nic nie może odwrócić globalnego zlodowacenia. ${ }^{11}$ Twórcy modeli klimatycznych nie wzięli pod uwagę aktywności wulkanicznej, która zapewniłaby dopływ dwutlenku węgla w okresie zlodowacenia, prowadząc w końcu do efektu cieplarnianego, w wyniku którego lód uległby szybkiemu roztopieniu. Modelowanie przeszłych zdarzeń to praca teoretyczna i chociaż można dzięki niemu formułować przewidywania, to jednak są one wiarygodne w takim samym stopniu, co założenia, na których opiera się model. Najlepsze, co można w takim wypadku zrobić, to szukać przewidywanych zjawisk w niepodlegającym kontroli świecie przyrody, a przy tym nie ma gwarancji - i to nawet przy założeniu, że rozpatrywana hipoteza jest słuszna — że rezultat takich poszukiwań będzie pomyślny. W ten sposób dochodzimy do kluczowej sprawy: mimo iż modele komputerowe mogą wskazać, czego szukać w przyrodzie, i mimo iż ślady i pewne założenia pomocnicze można badać w laboratorium, nie da się eksperymentalnie przetestować hipotezy historycznej jako takiej. Powtórzmy: przedział czasowy jest zbyt długi, a warunki testowe zbyt skomplikowane, by można je było odtworzyć w laboratorium.

\footnotetext{
${ }^{10}$ L.E. ORgeL, „The Origin of Life - A Review of Facts and Speculations”, Trends in Biochemical Science 1998, vol. 23, s. 491-495.

${ }^{11}$ P.F. Hoffman i D.P. Schrag, „Ziemia jak kula śniegu”, przeł. Marcin Ryszkiewicz, Świat Nauki, marzec 2000, nr 3 (103), s. 70-77.
} 
Podsumowując, Gee ${ }^{12}$ ma rację, że między naukami historycznymi a naukami eksperymentalnymi istnieją zasadnicze różnice metodologiczne. W ramach nauki eksperymentalnej uczeni skupiają się na jednej (czasem złożonej) hipotezie, zaś główna praktyka badawcza polega na wielokrotnym odtwarzaniu warunków testowych przewidywanych przez tę hipotezę oraz kontrolowaniu zewnętrznych czynników, które mogą prowadzić do wyników fałszywie pozytywnych lub wyników fałszywie negatywnych. Natomiast w naukach historycznych na ogół formułuje się wiele alternatywnych hipotez na temat poszczególnych przeszłych zdarzeń. Poszukiwany jest przede wszystkim domniemany dowód, czyli ślad umożliwiający uznanie jednej hipotezy za lepsze wyjaśnienie przyczynowe (zaobserwowanych śladów) niż pozostałe. Te różnice metodologiczne nie przemawiają jednak na rzecz poglą$\mathrm{du}$, że nauki historyczne są gorsze pod względem metodologicznym, odzwierciedlają one bowiem obiektywną różnicę między relacjami dowodowymi, z jakimi mają do czynienia badacze reprezentujący nauki historyczne i nauki eksperymentalne, dokonując ewaluacji swoich hipotez.

\section{Asymetria naddeterminacji}

Lokalne zdarzenia są najczęściej połączone przyczynowo w czasie w sposób asymetryczny. Na przykład erupcja wulkanu ma wiele różnych skutków (między innymi popiół, pumeks, masy bazaltu, chmury gazów), lecz już tylko mała ich część wystarczy do ustalenia, że erupcja nastąpiła. Mówiąc bardziej obrazowo, niepotrzebna jest do tego każda drobniutka cząstka popiołu. Wystarczy jeden $z$ tej ogromnej liczby niezwykle małych podzbiorów skutków. Z diametralnie odmienną sytuacją mamy jednak do czynienia, gdy rozpatrujemy ten proces w odwrotnym kierunku czasu. Przewidzenie erupcji jest znacznie trudniejsze niż ustalenie takiej, która już nastąpiła. W tym wypad$\mathrm{ku}$ istnieje zbyt wiele potencjalnie istotnych warunków (znanych i nieznanych), przy braku których erupcja nie dojdzie do skutku.

\footnotetext{
${ }^{12}$ Gee, In Search of Deep Time....
} 
Filozof David Lewis ${ }^{13}$ nazwał tę czasową asymetrię przyczynowości ,asymetrią naddeterminacji”. Chodzi zasadniczo o to, że lokalne teraźniejsze zdarzenia naddeterminują swoje przyczyny i poddeterminują swoje skutki. Być może najlepszym sposobem na zrozumienie, jaki zasięg ma asymetria naddeterminacji, jest uzmysłowienie sobie, jak trudno popełnić zbrodnię doskonałą. Trzeba wyeliminować na przykład odciski stóp i palców, cząsteczki skóry, nie pozwolić, aby wzniósł się kurz czy aby fale światła uleciały w przestrzeń. Nie wystarczy wyeliminować tylko kilku tych czynników. Wszystko, co umknie uwadze sprawcy, może zostać odkryte przez „Sherlocka Holmesa" i przyczynić się do skazania winowajcy. Co więcej, każdy ślad należy zatrzeć niezależnie. Nie można zatrzeć odcisku stopy poprzez usunięcie cząsteczki skóry lub, skoro już o tym mowa, zatarcie innego odcisku stopy. Natomiast - a jest to druga strona asymetrii naddeterminacji — zatarcie wszystkich śladów zbrodni przed jej popełnieniem zwykle wymaga jedynie jednego zabiegu: nienaciśnięcia spustu.

Istnieje spór co do fizycznego źródła asymetrii przyczynowości. Tłumaczono ją różnie: w kategoriach drugiego prawa termodynamiki (interpretowanego statystycznie), asymetrii radiacyjnej — zjawiska falowe (na przykład woda, światło) rozchodzą się ze swoich źródeł w przyszłość - oraz warunków początkowych Wszechświata. ${ }^{14} \mathrm{~Pa}-$ nuje jednak ogólna zgoda, że asymetria przyczynowości jest odzwierciedleniem obiektywnego i wszechobecnego zjawiska fizycznego, przynajmniej w przyrodniczej makroskali (na przykład wulkanów, skał, odcisków palców, skamieniałości, gwiazd).

Asymetria naddeterminacji wyjaśnia pozornie problematyczne różnice $\mathrm{w}$ testowaniu hipotez $\mathrm{w}$ naukach historycznych i naukach eksperymentalnych. Tak jak istnieje wiele różnych możliwości (podzbiorów śladów) wskazania przestępcy, tak też istnieją różne możliwości usta-

\footnotetext{
${ }^{13}$ D. LewIs, „Counterfactual Dependence and Time's Arrow”, w: F. JACKSON (ed.), Conditionals, Oxford University Press, Oxford, UK, s. 46-75.

${ }^{14}$ H. Price, Time's Arrow and Archimedes' Point, Oxford University Press, Oxford, UK 1996.
} 
lenia przyczyny wymarcia dinozaurów. Przedstawiciele nauk historycznych, podobnie jak detektywi, gromadzą świadectwa empiryczne, sprawdzają ,,podejrzanych” i podążają za śladami. Mówiąc ściślej, badają oni zaobserwowane ślady i postulują różne przyczyny, wśród których próbują następnie dokonać wyboru dzięki znalezieniu domniemanego dowodu - śladu, który wskazuje na swoją przyczynę niemalże bez żadnej wątpliwości.

Lewis ${ }^{15}$ explicite scharakteryzował asymetrię naddeterminacji w kategoriach wystarczalności przyczynowej. Może się ona jednak okazać zjawiskiem probabilistycznym. Podzbiory śladów mogą wskazywać na przyczynę jedynie $\mathrm{z}$ dużym prawdopodobieństwem, nie zaś ze stuprocentową pewnością. Badania eksperymentalne zawsze mają charakter zawodny - ma to związek z nieeliminowalną możliwością wpływu nieznanych warunków - i podobnie ślady odnajdywane w ramach badań terenowych nigdy nie umożliwiają konkluzywnego stwierdzenia, że postulowane zdarzenie naprawdę miało kiedyś miejsce. Powodem tego może być fakt, że nie odkryliśmy wystarczającej ilości śladów, lub to, że nie istnieją podzbiory śladów, które by na to pozwalały. Jednakże w obu przypadkach asymetria (quasi) naddeterminacji pomaga wyjaśnić metodologię nauk historycznych. Wskazuje ona, że już zdumiewająco niewielki podzbiór śladów pozwala $\mathrm{z}$ dużym prawdopodobieństwem ustalić, że w przeszłości nastąpiło jakieś określone zdarzenie, a ponadto, że najprawdopodobniej istnieje wiele takich podzbiorów. Istnienie tak wielu różnych możliwości nadania danej hipotezie dużego prawdopodobieństwa stanowi przesłankę do poszukiwania domniemanego dowodu.

Niekiedy to, co ma być takim domniemanym dowodem, można wywieść bezpośrednio z rozpatrywanej hipotezy. Świetnym przykładem jest kosmologiczna teoria Wielkiego Wybuchu. ${ }^{16}$ Zespół fizyków z Princeton, kierowany przez Roberta Dicke, przewidział, że jeżeli

\footnotetext{
${ }^{15}$ LEwIS, „Counterfactual Dependence...”.

${ }^{16}$ W. Kaufman, The Cosmic Frontiers of General Relativity, Brown, Little, Boston
} 1977. 
teoria Wielkiego Wybuchu jest prawdziwa, to Wszechświat powinien być wypełniony izotropowym, mikrofalowym promieniowaniem tha kosmicznego o temperaturze wyższej o kilka stopni od zera absolutnego. Późniejsze odkrycie tego tajemniczego promieniowania przez Wilsona i Penziasa uznano za decydujące świadectwo na rzecz teorii Wielkiego Wybuchu i przeciwko teorii stanu stacjonarnego. Czasem jednak ktoś ma po prostu szczęście i przypadkowo znajduje domniemany dowód, jak było w przypadku hipotezy, że dinozaury wyginęły W następstwie uderzenia meteorytu. ${ }^{17}$ Występowanie irydu i stopionego kwarcu na granicy K-T nie było przewidywane przed dokonaniem tego odkrycia. Co więcej, z upływem czasu ślady dawnych zdarzeń stają się coraz mniej wyraźne, aż wreszcie zupełnie się zacierają. Ewentualnie mogą w dalszym ciągu istnieć, lecz być w wielkim stopniu zamazane. Odnalezienie ich może wymagać bardziej zaawansowanych narzędzi technologicznych. Promieniowanie tła kosmicznego odkryto tylko dzięki stworzeniu bardzo czułych anten w celu komunikacji z satelitami. Iryd na granicy K-T odkryto natomiast za pomocą akceleratora cząstek (cyklotronu). Wreszcie, dany ślad może stracić status domniemanego dowodu w obliczu nowych świadectw empirycznych i wyjaśniających je hipotez. Metodologia nauk historycznych nie jest mniej zawodna niż metodologia nauk eksperymentalnych. Należy podkreślić, że nigdy nie można wykluczyć możliwości znalezienia domniemanego dowodu, co jest zresztą konsekwencją nadzdeterminowania przeszłości przez teraźniejszość. Jeśli taki dowód nie zostanie znaleziony, to dana hipoteza historyczna będzie pozbawiona empirycznego ugruntowania, przez co można ją uznać za zwykłą taką sobie bajeczkę.

Zastanówmy się teraz nad postępowaniem przedstawicieli nauk eksperymentalnych. Przyczyny zdarzeń są złożone. Rozważmy zwarcie, które spowodowało pożar domu. Gdyby nie to zwarcie, dom by nie spłonął. Istnieje jednak wiele innych czynników, które składają się na całkowitą przyczynę pożaru (na przykład obecność materiałów ła-

\footnotetext{
${ }^{17}$ Alvarez, Alvarez, Asaro, and Michel, „Extraterrestrial Cause...”.
} 
twopalnych lub brak instalacji tryskaczowej). Ponadto brak któregokolwiek z nich (w rzeczywistych okolicznościach) mógłby sprawić, że do pożaru w ogóle by nie doszło. Innymi słowy, konkretne zdarzenia (takie jak zwarcie), które zazwyczaj uznaje się za przyczynę późniejszych zdarzeń (pożaru domu), poddeterminują te przyszłe zdarzenia. Same w sobie nie stanowią wystarczającej podstawy przyczynowej, która zagwarantowałaby zaistnienie określonego skutku.

Podobnie jak nadztereminowanie przyczynowe przeszłych zdarzeń przez zdarzenia teraźniejsze tłumaczy postępowanie w naukach historycznych, tak podzdeterminowanie przyczynowe przyszłych zdarzeń przez zdarzenia teraźniejsze wyjaśnia praktyki w naukach eksperymentalnych. Warunki testowe w laboratorium stanowią jedynie częściową przyczynę późniejszego biegu zdarzeń. Trzeba zidentyfikować i kontrolować dodatkowe czynniki przyczynowe, gdyż w przeciwnym razie przekonanie o rzekomym potwierdzeniu lub obaleniu sprawdzanej hipotezy może być błędne. To dlatego uczeni reprezentujący nauki eksperymentalne poświęcają tyle czasu na odrzucenie, na gruncie metodologicznym, założeń pomocniczych, które wcześniej przyjęli. Nie próbują obalić własnych hipotez lub uchronić je przed obaleniem. Starają się natomiast ustalić wyniki fałszywie pozytywne i wyniki fałszywie negatywne, które zawsze stanowią zagrożenie, warunki testowe badane w laboratorium zazwyczaj stanowią bowiem tylko niewielki ułamek całkowitej przyczyny wyniku eksperymentu. Krótko mówiąc, działalność przedstawicieli nauk eksperymentalnych najlepiej interpretować jako próbę obejścia nieuniknionego podzdeterminowania przyczynowego wyników eksperymentów dzięki wyprowadzeniu warunków testowych ze sprawdzanej hipotezy.

\section{Podsumowanie}

Nauki historyczne nie znajdują się w gorszej sytuacji pod względem testowania hipotez niż nauki eksperymentalne. Tradycyjne ujęcia metody naukowej nie mogą potwierdzić wyższości badań eksperymentalnych. Co więcej, metodologiczne różnice, które rzeczywiście 
występują między naukami historycznymi a naukami eksperymentalnymi, mają związek z obiektywną i wszechobecną właściwością przyrody - asymetrią naddeterminacji. O ile uprawianie każdej z tych nauk polega na wybiórczym wykorzystywaniu różnych danych przyrodniczych, o tyle przekonanie, że hipotezy jednej z nich mają lepsze ugruntowanie w świadectwach empirycznych niż hipotezy drugiej, jest pozbawione podstaw.

\section{Podziękowania}

Badania, na podstawie których powstał niniejszy artykuł, częściowo sfinansowane zostały z grantu przyznanego Instytutowi Astrobiologii w University of Colorado przez National Aeronautics and Space Administration. Jestem wdzięczna Sheralee Brindell, Bruce'owi Jakosky'emu i Giffordowi Millerowi za cenne dyskusje i komentarze do pierwotnej wersji mojej pracy.

Carol E. Cleland 